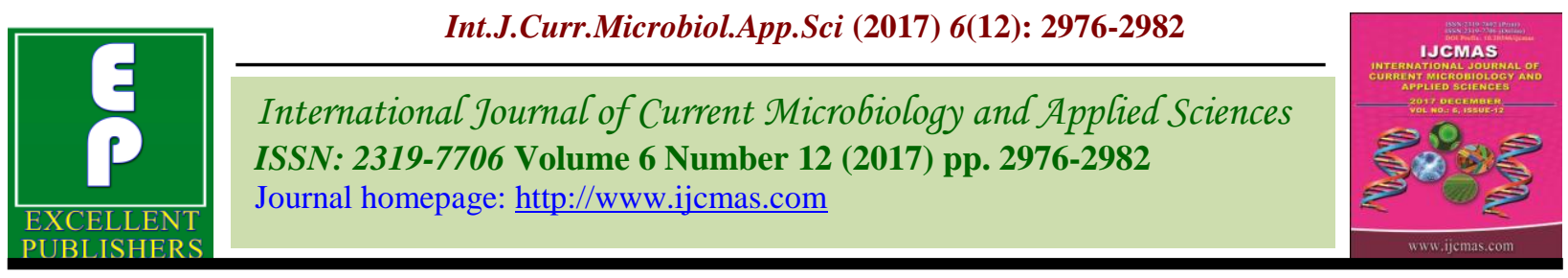

Original Research Article

https://doi.org/10.20546/ijcmas.2017.612.347

\title{
Physico-Chemical, Nutritional and Functional Properties of Roselle (Hibiscus sabdariffa L.)
}

\author{
V.H. Shruthi ${ }^{1 *}$, C.T. Ramachandra ${ }^{1}$, Udaykumar Nidoni ${ }^{1}$, \\ Sharanagouda Hiregoudar ${ }^{1}$, Nagaraj Naik ${ }^{2}$ and A.R. Kurubar ${ }^{3}$ \\ ${ }^{1}$ Department of Processing and Food Engineering, College of Agricultural Engineering, \\ University of Agricultural Sciences, Raichur- 584 104, Karnataka, India \\ ${ }^{2}$ AICRP on PHT, Department of Processing and Food Engineering, College of Agricultural \\ Engineering, University of Agricultural Sciences, Raichur- 584 104, Karnataka, India \\ ${ }^{3}$ Department of Horticulture, College of Agriculture, University of Agricultural Sciences, \\ Raichur- 584 104, Karnataka, India \\ *Corresponding author
}

A B S T R A C T

\begin{tabular}{|l|l}
\hline $\begin{array}{l}\text { Keywords } \\
\begin{array}{l}\text { Roselle calyces, } \\
\text { Physico-chemical } \\
\text { analyses, Nutritional } \\
\text { properties, }\end{array} \\
\begin{array}{l}\text { Antioxidant } \\
\text { properties. }\end{array}\end{array}$ & $\begin{array}{l}\text { The present investigation aimed to assess the physico-chemical, nutritional } \\
\text { and functional properties of fresh Roselle calyces. The fresh Roselle } \\
\text { calyces had considerable amount of crude protein, crude fat, carbohydrates, } \\
\text { crude fiber, total ash, ascorbic acid, total phenol, total flavonoid, total } \\
\text { anthocyanin and antioxidant properties. The present investigation showed } \\
\text { that the fresh Roselle calyces are generally acceptable as good source of } \\
\text { Article Info }\end{array}$ \\
\hline $\begin{array}{l}\text { Accepted: } \\
\begin{array}{l}\text { nutrients and antioxidant potentials. } \\
\text { Available } 2017 \\
10 \text { Online: }\end{array}\end{array}$ \\
\hline \hline
\end{tabular}

\section{Introduction}

Hibiscus subdariffa Linn. is a shrub belonging to the family - Malvaceae. It is thought to be a native to Asia (India to Malaysia) or Tropical Africa. The plant is widely grown in tropics like Caribbean, Central America, India, Africa, Brazil, Australia, Hawaii, Florida and Plilippines as a home garden crop. In addition to Roselle, in Englishspeaking regions it is called as Rozelle, Sorrel, Red sorrel, Jamanica sorrel, Indian sorrel, Guinea sorrel, Sour-sour, Queensland jelly plant, Jelly okra, Lemon bush and Florida cranberry. In Indian languages it is called as Lal-ambari, Patwa (Hindi), Lalambadi (Marathi), Gongura, Yerra gogu (Telugu), Pulichchai kerai (Tamil), Pulachakiri, Pundibija (Kannada), Polechi, Pulichchai (Malayalam) and Chukiar (Assam) (Mahadevan et al., 2009). Two botanical types of Roselle are recognized, Hibiscus sabdariffa var altissma and Hibiscus sabdariffa var subdariffa (Eltayeib and 
Hamade, 2014). The plant is about $3.5 \mathrm{~m}$ tall and has a deep penetrating taproot. It has a smooth or nearly smooth, cylindrical, typically dark green to red stems. Leaves are alternate, $7.5-12.5 \mathrm{~cm}$ long, green with reddish veins and long or short petioles. Leaves of young seedlings and upper leaves of older plants are simple; lower leaves are deeply 3 to 5 or even 7 -lobed and the margins are toothed.

Flowers, borne singly in the leaf axils are up to $12.5 \mathrm{~cm}$ wide, yellow or buff with a rose or maroon eye and turn pink as they wither at the end of the day. The typically red calyx, consists of 5 large sepals with a collar (epicalyx) of 8-12 slim, pointed bracts (or bracteole) around the base, they begin to enlarge at the end of the day, $3.2-5.7 \mathrm{~cm}$ long and fully enclose the fruit. The fruit is a velvety capsule, $1.25-2 \mathrm{~cm}$ long, which is green when immature, 5-valved, with each valve containing 3-4 seeds. The capsule turns brown and splits open when mature and dry. Seeds are kidney-shaped, light-brown, 3-5 $\mathrm{mm}$ long and covered with minute, stout and stellate hairs (Mahadevan et al., 2009).

The flowers of Roselle are generally small. Both the leaves and the fleshy base of the flower (the calyx) are employed in the preparation of soups and sauces. The vegetable is a popular diet during the rainy season. Roselle calyx is a cheap source of vegetable protein, fat and minerals. Regular consumption of Roselle may reduce nutritional deficiency problems such as night blindness, scurvy and rickets (Babalola et al., 2001; Ashaye, 2013). The types can be distinguished by three different colour groups: green, red and dark red. Calyces of the red and dark red coloured types are extracted and sweetened to produce a refreshing drink while calyces and leaves of the green type are used for making vegetable stew (Babalola et al., 2001).
Roselle has been used by people for preparing soft drinks and in traditional medicine. There are several reports on the benefits of Roselle calyces, as they are an excellent source of natural antioxidants, providing even higher levels than traditional sources such as raspberries and blueberries (Juliani et al., 2009).

It has been observed that its components, such as vitamins ( $\mathrm{C}$ and $\mathrm{E})$, polyphenols acids and flavonoids, mainly anthocyanins, have functional properties. Several studies have shown that compounds found in aqueous and ethanol Roselle calyces extracts might have antioxidant properties. These compounds could work in several ways in humans; for instance, they could have anticancer characteristics. They may also reduce chronic diseases such as diabetes mellitus, dyslipidemias, hypertension and cardiovascular diseases. Some of these compounds (flavonoids and anthocyanins) are natural which have no toxic or mutagenic effects (Ortega and Beltran, 2014).

Anthocyanins present in Roselle are dephinidin 3-sambubioside, cyaniding 3sambubioside, delphinidin 3-glucoside and cyanidin 3-glucoside. They contribute benefits for health as a good source of antioxidants as well as a natural food colourant (Kilima et al., 2014).

The main purpose of this study was to focus on determining the physico-chemical, nutritional and functional properties of fresh Roselle calyces. Results of these studies can be used to determine the fresh Roselle calyces have potent antioxidant properties and rich in nutrients. Hence, it is necessary to explore the possibility of utilizing the Roselle calyces for the preparation of different processed products and the application of calyces in a variety of food products as good source of nutrients. 
Materials and Methods

\section{Sample collection}

Freshly harvested Roselle samples were procured from M/s "Herbs n Health", Gadag, Karnataka, India.

\section{Sample preparation}

Fresh Roselle was selected uniformly according to harvest, colour and freshness. The calyces of Roselle were separated from seed capsules manually by hand picking. After separation of seed capsule from Roselle, the whole calyces were used for the analysis of physico-chemical, nutritional and functional properties. The fresh Roselle and fresh calyces of Roselle were depicted in Plate 1 and Plate 2.

\section{Physico-chemical analysis}

The $\mathrm{pH}$ of fresh calyces of Roselle were measured by using digital $\mathrm{pH}$ meter (Systronics; 361) according to method described by (Arab et al., 2011). The water activity of fresh calyces of Roselle was measured by Rotronic hygrolab water activity analyzer $\left(a_{w}\right.$-HP23) according to method described by (Manjula and Ramachandra, 2014). Hunter's lab colourimeter (Premier colourscan, Colour Flex EZ; Mumbai, India) was used for the measurement of colour $\left(L^{*}\right.$, $\left.a^{*}, b^{*}\right)$ of fresh calyces of Roselle samples. Titratable acidity was calculated as \% citric acid (AOAC, 2000) and ascorbic acid was determined using standard indophenol's method described by Ashaye (2013).

\section{Proximate analysis}

The proximate composition of the calyces of Roselle samples were determined using standard AOAC methods. The Roselle samples were analysed for moisture content
(AOAC 2000, 14.004) crude protein (AOAC 1990, 2.057), crude fat (AOAC 1990, 7.058), carbohydrates (AOAC 1990, 14.005) crude fiber (AOAC 1990, 14.020) and total ash (AOAC 1990, 14.006) content.

\section{Functional properties}

The total phenolic content of fresh Roselle extracts was determined with Folin Ciocalteau reagent by the method described by Sirag et al., (2014). Antioxidant activity of fresh extracts measured included radical scavenging activity and the free radical scavenging capacity of the extracts was determined using the 1,1-diphenyl-1picrylhydrazyl (DPPH) assay by the method described by Pacome et al., (2014). Total flavonoids content (TFC) of extract was determined using the method described by Wang et al., (2007) and the total anthocyanin content of extract was determined using the method described by Pacome et al., (2014).

\section{Results and Discussion}

\section{Physico-chemical analysis}

The physico-chemical properties of fresh calyces of Roselle viz., $\mathrm{pH}$, water activity, $L^{*}$ value, $a^{*}$ value, $b^{*}$ value, ascorbic acid and titratable acidity were estimated by standard procedure and the data obtained are presented in Table 1.

The average values of physico-chemical properties of fresh calyces of Roselle were found to be $\mathrm{pH}$ of $2.16 \pm 0.02$, water activity of $0.75 \pm 0.03, L^{*}$ value of $32.44 \pm 0.26, a^{*}$ value of $26.83 \pm 0.05, b^{*}$ value of $9.38 \pm 0.18$, ascorbic content of $46.36 \pm 0.49 \mathrm{mg} .100 \mathrm{~g}^{-1}$ and titratable acidity of $20.12 \pm 0.80 \%$. The result obtained was in close agreement with the literature value of Zaman et al., (2017), who reported that the fresh Roselle calyces had $\mathrm{pH}$ value of 2.07 , lower $L^{*}$ value of 28.76 , lower 
$a^{*}$ value of 18.82 , lower $b^{*}$ value of 3.22 , higher ascorbic content of $66.52 \mathrm{mg} \cdot 100 \mathrm{~g}^{-1}$ and titratable acidity of $20.22 \%$.

\section{Proximate analysis}

The results of proximate composition viz., moisture content, crude protein, crude fat, carbohydrates, crude fibre and total ash of fresh calyces of Roselle are presented in Table 2 and are discussed hereunder.

In the present investigation, average moisture content of fresh calyces of Roselle was found to be $86.08 \pm 0.65 \%$ (w.b.). The result was in good agreement with the literature values of Babalola et al., (2001), Fajar et al., (2012) and Langova et al., (2013) who reported the moisture content of fresh Roselle calyces as $86.50 \%$ (w.b.), $85.00 \%$ (w.b.) and $86.50 \%$ (w.b.), respectively. Zaman et al., (2017) reported the higher value of moisture content as $88.09 \%$ (w.b.) for fresh Roselle calyces. The average crude protein content of fresh calyces of Roselle was found to be $2.95 \pm 0.14 \%$. The results obtained were lower than the earlier studies reported by Zaman et al., (2017), who reported the protein content of $10.28 \%$ for fresh Roselle calyces. Mahadevan et al., (2009) reported the lower value of protein content as $1.46 \%$ for fresh Roselle calyces.

The average crude fat content of fresh calyces of Roselle was found to be $0.90 \pm 0.02 \%$. The results obtained were less than the earlier studies of Mahadevan et al., (2009), who reported the fat content of $2.61 \%$ for fresh Roselle calyces. The average carbohydrate content of the fresh calyces of Roselle was found to be $6.21 \pm 0.21 \%$. The result obtained was in close agreement with the literature value of Fasoyiro et al., (2005), who reported that the fresh Roselle calyces had carbohydrate content of $6.30 \%$. The average crude fibre content of the fresh calyces of Roselle was found to be $2.59 \pm 0.27 \%$. The result obtained was more than the findings of Gautam (2004), who reported the crude fibre content of fresh Roselle calyces as $1.58 \%$. The data pertaining to total ash content of fresh calyces of Roselle was observed as $1.09 \pm 0.02 \%$. This result is lower than the earlier studies of Mahadevan et al., (2009), who reported the total ash content of $6.90 \%$ for fresh Roselle calyces.

Plate.2 Fresh calyces of Roselle
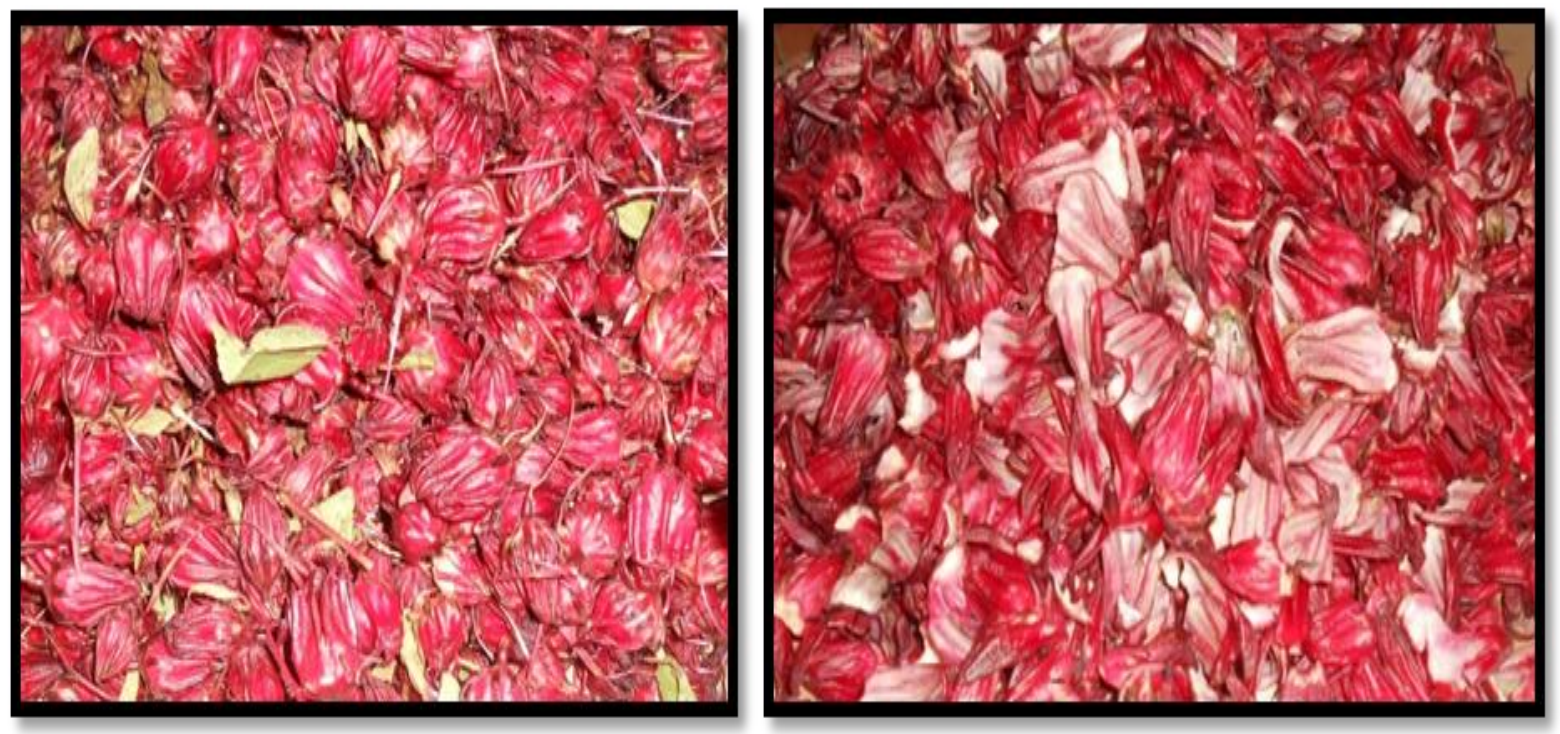
Table.1 Physico-chemical properties of fresh calyces of Roselle

\begin{tabular}{clc}
\hline Sl. No. & \multicolumn{1}{c}{ Parameter } & Average value \\
\hline 1 & pH & $2.16 \pm 0.02$ \\
2 & Water activity $\left(\mathrm{a}_{\mathrm{w}}\right)$ & $0.75 \pm 0.03$ \\
3 & $L^{*}$ & $32.44 \pm 0.26$ \\
4 & $a^{*}$ & $26.83 \pm 0.05$ \\
5 & $b^{*}$ & $9.38 \pm 0.18$ \\
6 & Ascorbic acid $\left(\mathrm{mg}^{*} 100 \mathrm{~g}^{-1}\right)$ & $46.36 \pm 0.49$ \\
7 & Titratable acidity $(\%)$ & $20.12 \pm 0.80$ \\
\hline
\end{tabular}

Values are triplicate and represent in Mean \pm STD

Table.2 Proximate composition of fresh calyces of Roselle

Values are triplicate and represent in Mean \pm STD

\begin{tabular}{clc}
\hline Sl. No. & \multicolumn{1}{c}{ Parameter } & Average value \\
\hline 1 & Moisture content (\%) (w.b.) & $86.08 \pm 0.65$ \\
2 & Crude protein (\%) & $2.95 \pm 0.14$ \\
3 & Crude fat (\%) & $0.90 \pm 0.02$ \\
4 & Carbohydrates (\%) & $6.21 \pm 0.21$ \\
5 & Crude fibre (\%) & $2.59 \pm 0.27$ \\
6 & Total ash (\%) & $1.09 \pm 0.02$ \\
\hline
\end{tabular}

Table.3 Functional properties of fresh calyces of Roselle

Values are triplicate and represent in Mean \pm STD

\begin{tabular}{clc}
\hline SI. No. & \multicolumn{1}{c}{ Parameter } & Average value \\
\hline 1 & Total phenolic content $\left(\mathrm{mg} \mathrm{GAE} \cdot \mathrm{g}^{-1}\right)$ & $20.85 \pm 0.08$ \\
2 & Antioxidant activity $(\%)$ & $92.23 \pm 0.77$ \\
3 & Total flavonoids $\left(\mathrm{mg} \mathrm{RE}^{-1} \mathrm{~g}^{-1}\right)$ & $38.34 \pm 0.11$ \\
4 & Total anthocyanin content $\left(\mathrm{mg} \mathrm{CyaG} .100 \mathrm{~g}^{-1}\right)$ & $718.72 \pm 1.19$ \\
\hline
\end{tabular}

\section{Functional properties}

The functional properties of fresh calyces of Roselle viz., total phenolic content, antioxidant activity, total flavonoids and total anthocyanin content were estimated by standard procedure and the data obtained are presented in Table 3.

The average functional properties of fresh calyces of Roselle were found to be total phenolic content of $20.85 \pm 0.08 \mathrm{mg}$ GAE. $\mathrm{g}^{-1}$, antioxidant activity of $92.23 \pm 0.77 \%$, total flavonoid content of $38.34 \pm 0.11 \mathrm{mg}$ RE. $\mathrm{g}^{-1}$ and total anthocyanin content of $718.72 \pm 1.19$ mg CyaG. $100 \mathrm{~g}^{-1}$. The result obtained were in close agreement with the literature value of Zaman et al., (2017), who reported that the fresh Roselle calyces had lower total phenolic content of $10.18 \mathrm{mg} \mathrm{GAE} \cdot \mathrm{g}^{-1}$, antioxidant activity of $92.12 \%$, lower total flavonoid content of $3.26 \mathrm{mg} \mathrm{RE} \cdot \mathrm{g}^{-1}$ and lower total anthocyanin content of $326.12 \mathrm{mg}$ CyaG.100g ${ }^{-1}$.

The variation in the physico-chemical, nutritional and functional properties of fresh calyces of Roselle procured from the M/s 'Herbs n Health' Gadag, Karnataka for the present investigation in comparison with the 
earlier studies might be due to the varietal difference, maturity stage, geographical area of cultivation and cultivation practices.

In summary, Roselle calyces could be good source of nutrients, therefore their consumption should be encouraged among the disadvantaged groups in developing countries. Roselle calyces could be used for the preparation of different processed products and the application of calyces in a variety of food products as good source of nutrients.

\section{References}

AOAC, 1990, Official methods of Analysis, $15^{\text {th }}$ edn. Assoc. of official Analytical Chemists, Arlington, VA.

AOAC, 2000, Official Methods of Analysis, $17^{\text {th }}$ edn. Assoc. of official Analytical Chemists, USA.

Arab, A. A., Salem, A. F. M. and Arab, E. A., 2011, Physico-chemical properties of natural pigments (anthocyanin) extracted from Roselle calyces (Hibiscus subdariffa). J. Am. Sci., 7(7): 445-456.

Ashaye, O. A., 2013, Studies on moisture sorption isotherm and nutritional properties of dried Roselle calyces. Int. Food Res. J., 20(1): 509-513.

Babalola, S. O., Babalola, A. O. and Aworth, O. C., 2001, Compositional attributes of the calyces of Roselle. J. Food Technol. Africa, 6(4): 133-134.

Eltayeib, A. A. and Hamade, H., 2014, Phytochemical and chemical composition of water extract of Hibiscus Sabdariffa (red karkade calyces) in North Kordofan state-Sudan. Int. J. Adv. Res. Chem. Sci. (IJARCS), 1(6): 10-13.

Fajar, B., Satriadi, H., Yuariski, O., Nugroho, R. S. and Shobib, A., 2012, Thin layer drying kinetics of Roselle. Adv. J. Food Sci. Technol., 4(1): 51-55.
Fasoyiro, S. B., Babalola, S. O. and Owosibo, T., 2005, Chemical composition and sensory quality of fruit-flavoured Roselle (Hibiscus sabdariffa) drinks. World J. Agric. Sci., 1(2): 161-164.

Gautam, R. D., 2004, Sorrel - a lesser-known source of medicinal soft drink and food in India. Nat. Prod. Rad., 3(5): 338-342.

Juliani, H. R., Welch, C. R., Wu, Q., Diouf, B., Malainy, D. and Simon, J. E., 2009, Chemistry and quality of Hibiscus (Hibiscus sabdariffa) for developing the natural-product industry in Senegal. $J$. Food Sci., 74(2): 113-121.

Kilima, B. M., Remberg, S. F., Chove, B. E. and Wicklund, T., 2014, Physiochemical, mineral composition and antioxidant properties of Roselle (Hibiscus sabdariffa L.) extract blended with tropical fruit juices. Afr. J. Food Agr. Nutr. Develop., 14(3): 8963-8978.

Langova, J., Jaisut, D., Thuwapanichayanan, R., Phowong, C., Stencl, J., Jovanovic, D., Fryc, J. and Vlasek, V., 2013, Modelling the moisture sorption isotherms of Roselle (Hibiscus sabdariffa L.) in the temperature range of 5-35 ${ }^{\circ}$ C. Acta Univ. Agric. et Silvic. Mendel. Brun., 61(6): 1769-1777.

Mahadevan, N., Shivali, and Kamboj, P., 2009, Hibiscus subdariffa Linn. - An overview. Nat. Prod. Rad., 8(1): 77-83.

Manjula, B. and Ramachandra, C. T., 2014, Effect of drying methods on physical and chemical characteristics of dried Byadagi chilli. J. Inno. Agric., 1(1): 2230.

Ortega, C. S. and Beltran, G. J. A., 2014, Roselle calyces particle size effect on the physicochemical and phytochemicals characteristics. J. Food Res., 3(5): 83-94.

Pacome, O. A., Bernard, D. N., Sekou, D., Joseph, D. A., David, N. D., Mongomake, K. and Hilaire, K. T., 2014, Phytochemical and antioxidant 
activity of Roselle (Hibiscus sabdariffa L.) petal extracts. Res. J. Pharm. Biol. Chem. Sci., 5(2): 1453-1465.

Sirag, N., Elhadi, M. M., Algaili, A. M., Hassan, H. M. and Ohaj, M., 2014, Determination of total phenolic content and antioxidant activity of Roselle (Hibiscus sabdariffa L.) calyx ethanolic extract. Standard Res. J. Pharm. Pharmacol., 1(2): 034-039.

Zaman, H. U., Das, P., Das, P. and Sahu, N. K., 2017, Analysis of physicochemical, nutritional and antioxidant properties of fresh and dried Roselle (Hibiscus sabdariffa Linn.) calyces. Int. J. Pure App. Biosci., 5(1): 261-267.

\section{How to cite this article:}

Shruthi, V.H., C.T. Ramachandra, Udaykumar Nidoni, Sharanagouda Hiregoudar, Nagaraj Naik and Kurubar, A.R. 2017. Physico-Chemical, Nutritional and Functional Properties of Roselle (Hibiscus sabdariffa L.). Int.J.Curr.Microbiol.App.Sci. 6(12): 2976-2982. doi: https://doi.org/10.20546/ijcmas.2017.612.347 